\title{
How the heat treatment affects the constituents of infant formulas: a review
}

\section{Como o tratamento térmico afeta os constituintes das fórmulas infantis: uma revisão}

\author{
Júlia d'Almeida Francisquini ${ }^{1}$ (1), Lauane Nunes ${ }^{1}$, Evandro Martins ${ }^{1}$, Rodrigo Stephani ${ }^{2}$, \\ Ítalo Tuler Perrone ${ }^{3}$ (D), Antônio Fernandes de Carvalho ${ }^{1 *}$ \\ ${ }^{1}$ Universidade Federal de Viçosa (UFV), Departamento de Tecnologia de Alimentos, Viçosa/MG - Brasil \\ ${ }^{2}$ Universidade Federal de Juiz de Fora (UFJF), Departamento de Química, Juiz de Fora/MG - Brasil \\ ${ }^{3}$ Universidade Federal de Juiz de Fora (UFJF), Departamento de Ciências Farmacêuticas, Juiz de Fora/MG - Brasil \\ *Corresponding Author: Antônio Fernandes de Carvalho, Universidade Federal de Viçosa (UFV), Departamento \\ de Tecnologia de Alimentos, Campus Universitário Viçosa, CEP: 36570-000, Viçosa/MG - Brasil, e-mail: \\ afc1800@yahoo.com
}

Cite as: Francisquini, J. D., Nunes, L., Martins, E., Stephani, R., Perrone, I. T., \& Carvalho, A. F. (2020). How the heat treatment affects the constituents of infant formulas: a review. Brazilian Journal of Food Technology, 23, e2019272. https://doi.org/10.1590/1981-6723.27219

\begin{abstract}
Breast milk as the children's primary source of nutrition fulfills the babies' needs and can also provide immune protection. In some cases, when mothers are not able to breastfeed, an equivalent substitute is required. Nowadays, the best substitutes of the human breast milk are infant formulas. Different technological routes may be designed to produce infant formulas according to the main challenges: the compromise between food safety and heat treatment damage. This article aimed to review the current scientific knowledge about how heat treatment affects the macro and micronutrients of milk, extrapolating the expected effects on infant formulas. The covered topics were: The definition and composition of infant formulas, industrial methods of infant formulas production, the effects of heat treatment on milk macro and micronutrients.
\end{abstract}

Keywords: Breastfeeding; Infant; Breast milk; Thermal processing; Browning reaction; Nutrients.

\section{Resumo}

O primeiro alimento do bebê é o leite materno, que deve, entre outras funções, atender, principalmente, às necessidades nutricionais e fornecer proteção imunológica. Em alguns casos, mães impossibilitadas de amamentar necessitam de substitutos. Nos dias de hoje, os substitutos que melhor mimetizam o leite humano são as fórmulas infantis. Diferentes rotas tecnológicas podem ser projetadas para produzir fórmulas infantis apresentando o grande desafio: o compromisso entre alimentos seguros e os danos causados pelo tratamento térmico. Este artigo foi elaborado com o objetivo de revisar o conhecimento científico atual sobre como o tratamento térmico afeta os macro e micronutrientes do leite, extrapolando os efeitos esperados para as fórmulas infantis. Os tópicos abordados são: definição e composição das fórmulas infantis, métodos industriais para produção de fórmulas infantis, efeito do tratamento térmico sobre macronutrientes e micronutrientes do leite.

Palavras-chave: Aleitamento materno; Criança; Leite materno; Processamento térmico; Reação de escurecimento; Nutrientes. 


\section{Introduction}

Breastfeeding is either essential for the baby's growth and development. It is known that diet plays an important role during the first years of the baby's life helping with the formation of eating habits, supporting the development of the immune system, and preventing diseases such as obesity, diabetes, hypertension, and atherosclerosis (Andreas et al., 2015; Zou et al., 2016).

The World Health Organization (WHO) recommends that breastfeeding should be exclusive for the first six months of the neonate's life and then must be gradually supplemented with another diet (Food and Agriculture Organization, 1981; Zou et al., 2016). Breast milk supplements the intrinsic deficiencies in newborns by providing immunological protection, preventing the onset of pathologies (infections, allergies, malnutrition), and meeting their nutritional needs (Blanchard et al., 2013).

However, in some cases, breastfeeding may be interrupted or not performed due to postpartum depression, insufficient milk syndrome, social factors (working mothers), or medical conditions (babies with metabolic disorders) (Pereyra Gonzáles et al., 2003). Based on the high risk of morbidity and mortality of nonbreastfeeding infants, the WHO recommends the implementation of artificial feeding (milk is taken directly from the mother, breast milk from milk banks, or commercial infant formulas - IF) when it is acceptable, feasible, accessible, sustainable, and also safe.

Although it is not always indicated, artificial feeding is a common practice, especially in underdeveloped countries, to provide the baby milk from other species, which may have a different composition compared to breast milk. Therefore, it should not be provided directly to the baby (Euclydes, 2014)

Microbiological contamination may be the main problem associated with infant formula production (Pei et al., 2018; Coppa et al., 2019; Portela et al., 2019; Zhuang et al., 2019). Different technological routes may be designed to produce infant formulas according to the main challenges: the compromise between food safety and heat treatment damage. This article was build aiming to review the current scientific knowledge about how heat treatment affects the macro and micronutrients of milk, extrapolating to the expected effects on infant formulas. The topics covered are definition and composition of infant formulas, industrial methods to produce infant formulas, the effect of heat treatment on macronutrients and micronutrients of milk.

\section{Definition and composition of infant formulas}

The Codex Alimentarius Committee (Codex) established by United Nations Organization is the main global regulatory agency for infant formulas, jointly by Food and Agriculture Organization (FAO) and the World Health Organization (WHO) in 1963. IF can be considered complete (adequate proportions of macronutrients, micronutrients, electrolytes, and trace elements) and may also use isolated proteins from cow's milk and intact or hydrolyzed soybeans. All other constituents/nutrients can be added separately regulated by law (Euclydes, 2014).

The formula composition should vary according to the child's growth and it can be further adjusted. Under the current regulations, Infant formulas can be classified into premature infants, infants (first six months), infants monitoring (from the age of six months), early childhood monitoring (from twelve months to three years old), and special formulas (Figure 1) (Food and Agriculture Organization, 1981; Blanchard et al., 2013). 
12

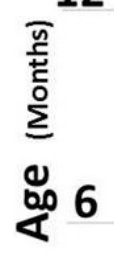

0

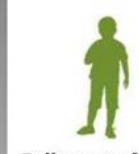

Follow-up for early childhood

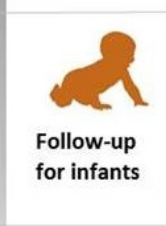

Less modified; similar composition of follow-up formulas for infants; protein adaptation and fat composition; addition of carbohydrates, vitamins and iron.

Present a greater compositional variety due to the wide age range Maltodextrin, glucose, sucrose and starch are commonly added; partial reduction of milk fat; addition of vegetable oil; reduction and modification of the casein/whey protein ratio

It presents as reference the composition of breast milk; may be added whey, lactose, maltose, dextrin, sucrose, vegetable oil, vitamins and iron; partially skimmed and demineralized.

Infants

High energy content; easily digestible carbohydrates; low molar mass nitrogen; addition of essential amino acids; mixture of milk Premature fat, vegetable oil, medium chain triacylglycerol (TCM) and lecithin.

Figure 1. Infant formula characteristics and functions according to the age of the infant. Adapted from Food and Agriculture Organization (1981); Blanchard et al. (2013); Euclydes (2014); Guo (2014).

Cow's milk, whey protein concentrate, demineralized whey, carbohydrates (lactose, maltodextrin, or sucrose), and vegetable oils were used as raw materials for infant formulas. If necessary, minerals such as iron may be added to the formulas. In $100 \mathrm{~mL}$ of the product ready for consumption, this type of formula must contain energy values between 60 and $70 \mathrm{kcal}$, protein 1.8 to $3.0 \mathrm{~g} 100 \mathrm{kcal}^{-1}$, total fat 4.4 to $6.0 \mathrm{~g}$

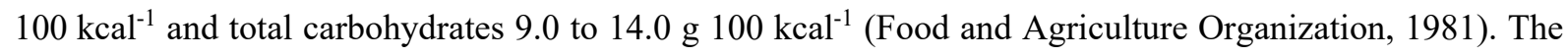
most common used Infant formulas (initial stages and the subsequent/following stages) and their compositions are shown in Table 1 (Food and Agriculture Organization, 1981).

Table 1. Composition of infant formulas for infants.

\begin{tabular}{|c|c|c|c|c|}
\hline \multirow{2}{*}{ Composition by 100 kcal } & \multicolumn{2}{|c|}{0 to 6 months } & \multicolumn{2}{|c|}{6 to 12 months } \\
\hline & Minimum & Maximum & Minimum & Maximum \\
\hline Energy, kcal* & 60 & 70 & 60 & 70 \\
\hline Protein, $g$ & 1.8 & 3.0 & 1.8 & 3.5 \\
\hline Lipids, g & 4.4 & 6.0 & 4.0 & 6.0 \\
\hline Acid. Linoleic, mg & 300 & 1400 & 300 & 1400 \\
\hline Acid. Linolenic, mg & 50 & NS & 50 & $\mathrm{NS}$ \\
\hline Relation n-6: n-3 & $5: 1$ & $15: 1$ & $5: 1$ & $15: 1$ \\
\hline Carbohydrates & 9.0 & 14 & 9.0 & 14 \\
\hline Vit. A, $\mu \mathrm{g}$ RE & 60 & 180 & 60 & 180 \\
\hline Vit. D, $\mu \mathrm{g}$ & 1.0 & 2.5 & 1.0 & 3.0 \\
\hline Vit. $K, \mu g$ & 4.0 & - & 4.0 & - \\
\hline Vit. E, mg $\alpha$-TE & 0.5 & - & 0.5 & - \\
\hline Thiamine, $\mu \mathrm{g}$ & 60 & - & 60 & - \\
\hline Riboflavin, $\mu \mathrm{g}$ & 80 & - & 80 & - \\
\hline Niacin, $\mu \mathrm{g}$ & 300 & - & 300 & - \\
\hline Vit. B6, $\mu \mathrm{g}$ & 35 & - & 35 & - \\
\hline Vit. B12, $\mu \mathrm{g}$ & 0.1 & - & 0.1 & - \\
\hline Ac. Pant., $\mu \mathrm{g}$ & 400 & - & 400 & - \\
\hline
\end{tabular}


Table 1. Continued..

\begin{tabular}{|c|c|c|c|c|}
\hline \multirow{2}{*}{ Composition by 100 kcal } & \multicolumn{2}{|c|}{0 to 6 months } & \multicolumn{2}{|c|}{6 to 12 months } \\
\hline & Minimum & Maximum & Minimum & Maximum \\
\hline Folic acid, $\mu \mathrm{g}$ & 10 & - & 10 & - \\
\hline Vit. C, mg & 10 & - & 10 & - \\
\hline Biotin, $\mu \mathrm{g}$ & 1.5 & - & 1.5 & - \\
\hline Iron, mg & 0.45 & - & 0.9 & 2 \\
\hline Calcium, mg & 50 & - & 50 & - \\
\hline Phosphor, mg & 25 & - & 25 & - \\
\hline Magnesium, mg & 5.0 & - & 5.0 & - \\
\hline Sodium, mg & 20 & 60 & 20 & 60 \\
\hline Chlorine, $\mathrm{mg}$ & 50 & 160 & 50 & 160 \\
\hline Potassium, mg & 60 & 180 & 60 & 180 \\
\hline Manganese, $\mu \mathrm{g}$ & 1.0 & - & 1.0 & - \\
\hline Iodine, $\mu \mathrm{g}$ & 10 & - & 10 & - \\
\hline Selenium, $\mu \mathrm{g}$ & 1.0 & - & 1.0 & - \\
\hline Copper, $\mu \mathrm{g}$ & 35 & 120 & - & 120 \\
\hline Zinc, mg & 0.5 & - & 0.5 & - \\
\hline Choline, $\mathrm{mg}$ & 7.0 & - & 7.0 & - \\
\hline Inositol, mg & 4.0 & - & 4.0 & - \\
\hline L- carnitine, mg & 1.2 & - & - & - \\
\hline
\end{tabular}

Source: Adapted from Food and Agriculture Organization (1981). NS = not specified. *Energy expressed as kcal per $100 \mathrm{~mL}$.

Most proteins come from cow's milk and whey. It is necessary to adapt the ratio of whey/casein proteins to promote better digestibility, metabolic overload reduction, and infant's nutritional needs. The levels of essential and semi-essential amino acids in the milk formula must be at least equivalent to the reference protein (human milk) (Blanchard et al., 2013).

The human milk fat composition differs from cow's milk and the historical development of infant formulas presented three stages of evolution considering human milk fat substitution over the years: stage 1 - focus on energy replacement (1856 to 1910-1920), stage 2 - focus on energy replacement and fatty acid composition (1910-1920 to 1990), stage 3 - focus on energy replacement, fatty acid composition, triacylglycerol and complex lipids (Wei et al., 2019).

There is a reduction in the amount of saturated fat in the formula as the lipid in this formula will partly be derived from the dairy fat and partly from different vegetable sources such as soybeans, corn, sunflower, and canola. Also, there is a need to improve the digestion and absorption of calcium to adjust the composition of essential fatty acids (Euclydes, 2014; Guo, 2014). The content of trans fats in the formulas should be minimal, around 3\% of total fatty acids, as recommended by Codex (Thompkinson \& Kharb, 2007).

Gastrointestinal disorders (including constipation) in babies are related to the consumption of vegetable oil-based infant formulas which are mainly associated with long chain saturated fats esterified at sn-1 and sn-3 positions (breast milk has fatty acids esterified at the sn-2 position) (Mehrotra et al., 2019).

Most of the present formulas require the external addition of lactose to match the amount contained in human milk. However, in some cases, the mixtures of some carbohydrates such as sucrose, maltodextrin, glucose polymers, and starch can be supplemented as well. All formulas must be enriched with iron and also must have the same osmolarity as breast milk $\left(<460 \mathrm{mOs} \mathrm{mL}^{-1}\right)$ (Euclydes, 2014; Andreas et al., 2015).

Some ingredients can be added to further reach the standards of breast milk, such as nucleotides which help in the maturation of the gastrointestinal tract and invoke immunomodulatory effects, long-chain fatty acids (arachidonic and docosahexaenoic), which are responsible for physiological and metabolic functioning; 
probiotics and prebiotics, associated with pathogenic inhibition and immunomodulation, and amylopectin, used for children with gastroesophageal reflux (Euclydes, 2014).

\section{Industrial methods for production of infant formulas}

Infant formulas are found in two readily consumable forms: liquid concentrate and powder form. However, the liquid version presents an elevated price due to the production expenses, transportation, and distribution. Also, a short shelf life requires appropriate refrigeration and extra care with the packaging avoiding potential contamination (Kliegman et al., 2014). Therefore, the powdered version represents the major formula available in the market which can be manufactured using "dry mix" or "wet/spray" processes (Guo, 2014; Schmitz-Schug et al., 2016).

The ingredients in the dry mix process are first mixed in powder form and then packaged. This method includes some advantages as lower energy expenditure during production and less investment in equipment, construction, and maintenance. However, microbiological safety may be questioned since it depends on the quality of the raw materials used to assemble the final product. Moreover, the major problems are associated with post-processing contamination with Salmonella and other Enterobacteriaceae, including Enterobacter sakazakii, associated with food-poisoning outbreaks (Song et al., 2018).

To minimize the microbiological risks associated with dry mixing protocols, the wet method represents the most commonly used procedure for the powder formula production, using better monitoring and control of the process steps (Blanchard et al., 2013; Guo, 2014; Schmitz-Schug et al., 2016). Initially, the raw material in powder form is mixed with water and oil, and then pasteurized, homogenized, and concentrated under vacuum until the obtention of a solid concentration between $40 \%$ and $50 \%$ (Figure 2) (Blanchard et al., 2013; Schmitz-Schug et al., 2016).

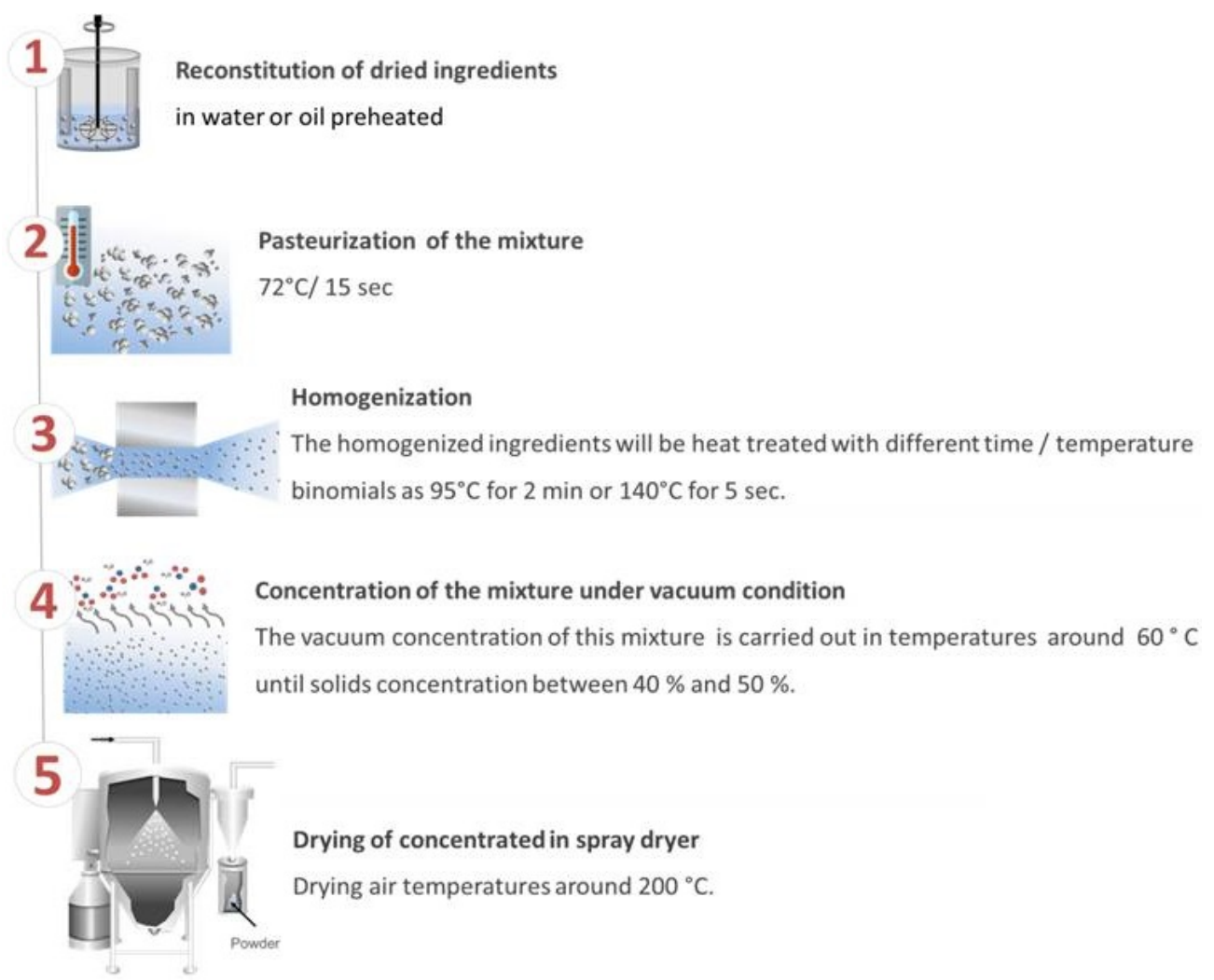

Figure 2. Steps of production of infant formulas by wet via. Adapted from Blanchard et al. (2013); Kliegman et al. (2014); Schmitz-Schug et al. (2016); Song et al. (2018). 
Through this process, the fluid material is transformed into dried particles by spraying into a heated atmosphere (Figure 2). When the homogenized mixture comes in contact with drying air, there is evaporation in the droplets until the moisture content becomes too low to diffuse through the dry droplet surface. Finally, the recovery of dry powder is carried out in the cyclone (Keshani et al., 2015). The last stage is coupled to an adequate packaging process with minimal microbiological contamination. The appropriate packaging process improves the product shelf life, avoiding deterioration, oxidation, and agglomeration of particles.

\section{The effect of heat treatment on infant formulas}

\subsection{The effect of heat treatment on macronutrients}

Upon heat treatment, several irreversible changes in the composition of milk macronutrients can occur (Qian et al., 2017). Milk proteins are among the most heat-sensitive substances. However, caseins rich in proline and naturally unfolded will be less affected by heat when compared to whey proteins (Raikos, 2010).

Casein micelle size distribution, chymosin coagulation, and thermal stability are normally recovered by milk reconstitution after drying. However, this protein may undergo chemical and structural changes during the milk heating process, which may affect the profile of bioactive peptides produced during protein digestion (Souza et al., 2015).

Finally, after intense heating process casein molecules may be cleaved, leading to their dephosphorylation. Also, severe heat treatment can also cleave peptide chains which produce soluble peptides (Xu et al., 2016).

The glycosylated state of $\kappa$-casein inhibits Helicobacter pylori in human gastrointestinal mucosa owing to its structural similarity with SIgA. However, $\kappa$-casein can be deglycosylated upon heating, promoting the loss of its protective function (Lönnerdal et al., 2017). Besides, at high temperatures, a great amount of calcium phosphate associated with casein micelles results in increasing dissociation of $\kappa$-casein and decreasing product stability (Borad et al., 2017).

Heat treatments result in loss of function of $\beta$-casein as main responsible for the high bioavailability of calcium and zinc in human milk. Thus, this sub-category of casein protein has a great role in the development and growth of the infant by increasing the bioavailability of minerals in human milk. Consequently, the loss of its function would result in future problems for the child (Lönnerdal et al., 2017).

Whey proteins are more susceptible to heat treatment leading to possible alteration of functional and nutritional characteristics. Denaturation of whey proteins is the most important reaction during the heat treatment of dairy products. Whey proteins may undergo irreversible denaturation, affecting their threedimensional conformation and functional properties (water absorption, gelling, emulsification, and viscosity) (Golkar et al., 2019).

Whey proteins may also interact with casein micelles, resulting in aggregation/dissociation of micelles (specifically, $\kappa$-casein micelles) decreasing the solubility of milk proteins. These associations modify the micellar surface, leading to an alteration of hydrophobicity and functionality of the reconstituted dairy products. Also, as a result of this aggregation, most proteins lose their biological activity, eventually promoting protein coagulation (Souza et al., 2015; Raikos, 2010; Borad et al., 2017; Qian et al., 2017). Also, a few of whey proteins, especially $\beta$-lactoglobulin, bind covalently to membrane proteins of fat globules (Liu et al., 2012).

The $\alpha$-lactalbumin may lose calcium and zinc-binding ability followed by a decrease in the bioavailability of these nutrients. On the other hand, lactoferrin tends to lose its microbial action due to heating (Golinelli et al., 2014). Although $\beta$-lactoglobulin does not exist in human milk, it is present in IF derived from cow's milk and it can be denatured or even become insoluble during heat treatments (Rafe \& Razavi, 2015). 
Besides lipids aggregation with casein, heat cycles can favor the hydrolysis and interesterification of glycerides subsequently changing the quality and quantity of short-chain fatty acids (C4:0, C6:0, and C8:0) in infant formulas (Pestana et al., 2015). Milk fat globule membrane (MFGM) derives from the mammary gland epithelium and it is primarily composed of polar lipids with interspersed membrane-bound proteins, glycoproteins, enzymes, and cholesterol which results in a bioactive molecule that provides some of the important protective features of breast milk. However, most infant formulas do not contain MFGM. Recent breakthroughs in manufacturing technologies permit the concentration of bovine MFGM, enabling to add MFGM into IF. Nevertheless, heat treatment can result in an enhanced permeability of MFGM, affecting its stability (Liu et al., 2016; Liu et al., 2012).

Heating the milk can also inactivate the enzyme superoxide dismutase in addition to allowing copper to move from the plasma to the fat globules membrane. Such a situation can lead to dairy product oxidation. The temperature to which fat is subjected to bears a significant effect on the amount, composition, and stability of fat crystals. Also, prolonged heating and storage initiate induction of lactose crystallization and increased water activity accelerating the lipid oxidation (Walstra et al., 2006).

Also, heat treatment can also result in the breakdown of phospholipids with a consequent increase in the amount of inorganic phosphate (Walstra et al., 2006). To conclude, lipids can carry liposoluble vitamins (A, D, E, and $\mathrm{K}$ ) and are precursors for the synthesis of hormones involved in the modulation of immune and inflammatory responses. They are important components of cell membranes, essential for the development of the central nervous system and the children's retina. Lipids also improve the processes involved in information codification, storage, and memory recovery; or psychomotor processes. Thus, they may lose these fundamental functions due to alteration upon heating (Zou et al., 2016).

Apart from what we know about these macronutrients, we may consider that the higher protein content, lower concentrations of long-chain polyunsaturated fatty acids, and presumably the lack of insulin-sensitizing hormones, along with numerous other biologically active substances in infant formulas, play a pathophysiological role, for example in insulin sensitivity (Klenovics et al., 2013).

Heat treatment can also affect carbohydrates. The isomerization of lactose into lactulose and organic acids is one of the common consequences of heating. Lactulose is a disaccharide, formed by fructose and galactose residues obtained upon the isomerization of lactose, which may occur in the alkaline environment or during the heat processing of milk. Unlike lactose, lactulose cannot be hydrolyzed by human intestinal enzymes. However, it can be fermented by bacterias present in the colon, mainly by Bifidobacterium sp., which acts as prebiotics (Zhang et al., 2010). Lactulose is the main resultant compound formed during the heat treatment of the milk and its formation is relative to the subjected heat intensity. Based on this characteristic, the amount of lactulose in the heated dairy products can be used as an indicator of the intensity of the heat treatment (Walstra et al., 2006).

Besides forming lactulose lactose can also react with amino acids, peptides, or proteins by Maillard reaction. This non-enzymatic browning reaction is one of the main non-enzymatic reactions responsible for reducing the quality of dairy products when heated and continued to be stored (Deeth \& Hartanto, 2009).

The Maillard-induced conjugation can lead to the glycation of proteins and peptides (glucose or lipids bind to the proteins permanently). This leads to changes in physicochemical properties and technological functionality (solubility, heat stability, emulsification, foaming, and gelation properties) of milk proteins and peptides and their derivatives (Torres et al., 2017). The Maillard reaction in infant formula can result in the formation of products such as furfural and carboxymethyl lysine, which are often associated with the reduction/loss of the nutritional values imparted by the essential amino acids such as arginine, lysine, methionine, and tryptophan, as well as reducing the digestibility of the food for the infant (Mehta \& Deeth, 2016). When these products are combined with advanced glycation end products (AGEs) (formed by glycation), they can result in an excessive endogenous pool in those who ingested infant formulas (Vistoli et al., 2013). 
Despite the reported disadvantages, Maillard reaction under dry conditions seems to be an effective way of reducing the antigenicity of cow's milk proteins. This is because allergens (proteins) are modified by this reaction (Golkar et al., 2019). The higher and earlier the exposure and ingestion of such products happen, the higher will be the interference on the child's health. Thus, an excessive endogenous pool in childhood may render a pathogenic role in the development and progression of different oxidative diseases in adulthood. These include diabetes, insulin resistance, chronic renal failure, cardiovascular diseases (atherosclerosis), neurological disorders (Alzheimer's disease), aging, oxidative stress, protein damage, reduced blood vessel elasticity, vascular thickening, hypertension, endometrial dysfunction, retinal pathology, osteoporosis, and arthritis (Vistoli et al., 2013).

In short, during intense heating lactose can either be decomposed into lactulose or participate in the Maillard reaction and the main results are changes in flavor and brown color development due to the appearance of melanoidins, which is also followed by loss of nutritional value due to the decrease of lysine to be absorbed by the intestines (Walstra et al., 2006).

Additionally, caramelization reaction can be mentioned as a common phenomenon with dairy products after a short time heating process. In this case, the sugars are pyrolyzed in caramel (high molecular weight and dark degradation products) (Araújo, 2008). Such reactions may result in browning of foods, loss of lysine, modification of flavor, the formation of hydroxymethylfurfural and melanoidins, and even carbonization of food if the heat treatment continues (Fennema et al., 2010).

\subsection{The effect of heat treatment on micronutrients}

The liposoluble vitamins $\mathrm{A}, \mathrm{D}, \mathrm{E}$, and $\mathrm{K}$ and a few of the $\mathrm{B}$ complex vitamins like biotin and riboflavin are relatively stable despite heat treatment of infant formulas. The water-soluble vitamins like vitamin $\mathrm{C}$ and thiamine are the most affected by heat treatment as they are more unstable and naturally oxidized by air (Sucupira et al., 2012). Also, significant reductions in the levels of niacin, pyridoxine, cobalamin, and folate have been reported under the influence of different milk processing treatments (Asadullah et al., 2010).

Oxidation leads to the loss of ascorbic acid (vitamin C), which acts as an antioxidant, helps in strengthening the immune system and blood capillaries, preventing of flu and infections (Araújo, 2008). Vitamin $\mathrm{C}$ also resists the bones and teeth by helping the absorption of iron, along with regulating the metabolism of a few amino acids. Also, vitamin C, under the effect of heating leads to the formation of dark pigments that promote changes in the color, texture, and flavor of the food (Fennema et al., 2010). Besides nutrition, vitamin $\mathrm{C}$ is added to infant formula to contribute technologically by enhancing the chemical stability of the product due to its antioxidative role. If necessary, the addition of vitamins (A, D, E) may also be done. The vitamin loss is variable and depends on the time/temperature binomial to which the product is subjected. Prolonged heating time is more responsible for the destruction of vitamins than the temperature itself (Leskova et al., 2006).

Among the minerals, calcium is one of the most affected by heat as it can be internalized in the casein micelles and become unavailable for the absorption of the child. Calcium can be lost during heating through fouling in the equipment along with other minerals and proteins (Gaucheron, 2005). Besides calcium, the inorganic phosphate content also becomes very high due to the hydrolysis of phosphate esters of casein and phospholipids, decreasing the availability of phosphorus. Also, it is a common practice to fortify the milk with iron and copper (Walstra et al., 2006).

\section{Conclusions}

The main impacts of the heat treatment to macronutrients of milk are loss of function of $\beta$-casein (mainly responsible for the high bioavailability of calcium and zinc in human milk), $\alpha$-lactoalbumin loses the calcium and zinc-binding ability (decrease in the bioavailability of these nutrients), lactoferrin tends to lose its 
microbial action, quality and quantity of short-chain fatty acids (C4:0, C6:0, and C8:0) modifications in infant formulas, breakdown of phospholipids, and Maillard reaction in infant formula may result in the formation of products such as furfural and carboxymethyl lysine (associated with the reduction/loss of the nutritional values imparted by the essential amino acids such as arginine, lysine, methionine, and tryptophan, as well as reducing the digestibility of the food for the infant).

The main impacts of the heat treatment to micronutrients of milk are: oxidation of the water-soluble vitamins like vitamin $\mathrm{C}$ and thiamine, liposoluble vitamins $\mathrm{A}, \mathrm{D}, \mathrm{E}$, and $\mathrm{K}$, biotin, and riboflavin are relatively stable, among the minerals, calcium is one of the most affected by heat as it can be internalized in the casein micelles and become unavailable for the absorption of the child.

According to the scientific literature, there are several damages to milk components caused by heat treatment as those applied in infant formula production. As a consequence, food safety and heat treatments damage are still the big challenges for infant formula production. Therefore, the design of new routes for infant formula production is necessary, based on new non-thermic technologies and membrane filtration. These technologies seek to reduce energy consumption and the damages to the milk components providing new high nutritional value for infant formulas based on milk.

\section{Acknowledgements}

We acknowledge CNPq, FAPEMIG, and CAPES for financial support and research grants.

\section{References}

Andreas, N. J., Kampmann, B., \& Mehring Le-Doare, K. (2015). Human breast milk: A review on its composition and bioactivity Early Human Development, 91(11), 629-635. PMid:26375355. http://dx.doi.org/10.1016/j.earlhumdev.2015.08.013

Araújo, J. M. (2008). Química de alimentos (5. ed.). Viçosa: Editora UFV.

Asadullah, K. N., Tarar, O. M., Ali, S. A., Jamil, K., \& Begum, A. (2010). Study to evaluate the impact of heat treatment on water soluble vitamins in milk. JPMA. The Journal of the Pakistan Medical Association, 60(11), 909-912. PMid:21375192.

Blanchard, E., Zhu, P., \& Schuck, P. (2013). Infant formula food powders. In B. Bhandari, N. Bansal, M. Zhang \& P. Schuck (Eds.), Handbook of food powders (1st ed.). United Kingdom: Woodhead Publishing. http://dx.doi.org/10.1533/9780857098672.3.465.

Borad, S. G., Kumar, A., \& Singh, A. K. (2017). Effect of processing on nutritive values of milk protein. Critical Reviews in Food Science and Nutrition, 57(17), 3690-3702. PMid:27052328. http://dx.doi.org/10.1080/10408398.2016.1160361

Coppa, C. F. S. C., Khaneghah, A. M., Alvito, P., Assunção, R., Martins, C., \& Ismail, E. S. (2019). The occurrence of mycotoxins in breast milk, fruit products and cereal-based infant formula: a review. Trends in Food Science \& Technology, 92, 81-93. http://dx.doi.org/10.1016/j.tifs.2019.08.014

Deeth, H. C., \& Hartanto, J. (2009). Chemistry of milk—role of constituents in evaporation and drying. In A. Y. Tamime (Ed.) Dairy powders and concentrated products (1st ed.). USA: John Wiley \& Sons. https://doi.org/10.1002/9781444322729.ch1.

Euclydes, M. P. (2014). Nutrição do lactente: Base científica para uma alimentação saudável (1. ed.). Viçosa: Editora UFV. Fennema, O. R., Srinivasan, D., \& Kirk, L. P. (2010). Química de alimentos de Fennema (4. ed.). Porto Alegre: Artmed.

Food and Agriculture Organization - FAO. Codex Alimentarius Commission - CAC. (1981). Joint FAOWHO Food Standards Programme. Standard for infant formula and formulas for special medical purposes intended for infants. Adopted as a worldwide standard in 1981. Amendment: 1983, 1985, 1987, 2011 and 2015. Revision: 2007.CAC/STAN 72-1981. Rome.

Gaucheron, F. (2005). The minerals of milk. Reproduction and Nutrition, 45(4), 473-483. PMid:16045895. http://dx.doi.org/10.1051/rnd:2005030

Golinelli, L. P., Delaguila, E. M., Paschoalin, V. M. F., Silva, J. T., \& Conte, J. C. A. (2014). Functional aspect of colostrum and whey proteins in human Milk. Journal of Human Nutrition and Food Science, 2(3), 1-9.

Golkar, A., Milani, J. M., \& Vasiljevic, T. (2019). Altering allergenicity of cow's milk by food processing for applications in infant formula. Critical Reviews in Food Science and Nutrition, 59(1), 159-172. PMid:29658775. http://dx.doi.org/10.1080/10408398.2017.1363156

Guo, M. (2014). Human milk biochemistry and infant formula manufacturing technology (1st ed.). United Kingdom: Woodhead Publishing.

Keshani, S., Daud, W. R. W., Nourouzi, M. M., Namvar, F., \& Ghasemi, M. (2015). Spray drying: an overview on wall deposition, process and modeling. Journal of Food Engineering, 146, 152-162. http://dx.doi.org/10.1016/j.jfoodeng.2014.09.004 
Klenovics, K. S., Boor, P., Somoza, V., Celec, P., Fogliano, V., \& Sebeková, K. (2013). Advanced glycation end products in infant formulas do not contribute to insulin resistance associated with their consumption. PLoS One, 8(1), e53056. PMid:23301020. http://dx.doi.org/10.1371/journal.pone.0053056

Kliegman, R., Stanton, B. M., Geme, J. S., \& Schor, N. F. (2014). Tratado de pediatria (19. ed.). Rio de Janeiro: Elsevier. Leskova, E., Kubikova, J., Kovacikova, E., Kosicka, M., Porubska, J., \& Holcikova, K. (2006). Vitamin losses: retention during heat treatment and continual changes expressed by mathematical models. Journal of Food Composition and Analysis, 19(4), 252-276. http://dx.doi.org/10.1016/j.jfca.2005.04.014

Liu, G., Li, Y., Cao, J., Ren, D., Yuan, D., \& Zhang, L. (2012). Changes of microbiological and physicochemical properties in Chinese infant formula caused by high heat treatment applied on concentrated milk. Dairy Science \& Technology, 92(6), 719733. http://dx.doi.org/10.1007/s13594-012-0089-y

Liu, Z., Roy, N. C., Guo, Y., Jia, H., Ryan, L., Samuelsson, L., Thomas, A., Plowman, J., Clerens, S., Day, L., \& Young, W. (2016). Human breast milk and infant formulas differentially modify the intestinal microbiota in human infants and host physiology in rats. The Journal of Nutrition, 146(2), 191-199. PMid:26674765. http://dx.doi.org/10.3945/jn.115.223552

Lönnerdal, B., Erdmann, P., Thakkar, S. K., Sauser, J., \& Destaillats, F. (2017). Longitudinal evolution of true protein, amino acids, and bioactive proteins in breast milk: A developmental perspective. The Journal of Nutritional Biochemistry, 41, 1-11. PMid:27771491. http://dx.doi.org/10.1016/j.jnutbio.2016.06.001

Mehrotra, V., Sehgal, S. K., \& Bangale, N. R. (2019). Fat structure and composition in human milk and infant formulas: implications in infant health. Clinical Epidemiology and Global Health, 7(2), 153-159. http://dx.doi.org/10.1016/j.cegh.2018.03.005

Mehta, B. M., \& Deeth, H. C. (2016). Blocked lysine in dairy products: formation, occurrence, analysis, and nutritional implications. Comprehensive Reviews in Food Science and Food Safety, 15(1), 206-218. http://dx.doi.org/10.1111/15414337.12178

Pei, X., Yang, S., Zhan, L., Zhu, J., Song, X., Hu, X., Liu, G., Ma, G., Li, N., \& Yang, D. (2018). Prevalence of Bacillus cereus in powdered infant and powdered follow-up formula in China. Food Control, 93, 101-105. http://dx.doi.org/10.1016/j.foodcont.2018.05.049

Pereyra Gonzáles, G. A. S., Naranjo, G. B., Malec, S., \& Vigo, M. S. (2003). Available lysine, protein digestibility and lactulose in commercial infant formulas. International Dairy Journal, 13(2-3), 95-99. http://dx.doi.org/10.1016/S0958-6946(02)00173-5

Pestana, M. J., Gennari, A., Monteiro, B. W., Lehn, D. N., \& Souza, C. F. V. (2015). Effects of pasteurization and ultra-high temperature processes on proximate composition and fatty acid profile in bovine milk. American Journal of Food Technology, 10(6), 265-272. http://dx.doi.org/10.3923/ajft.2015.265.272

Portela, J. B., Coimbra, P. T., Cappato, L. P., Alvarenga, V. O., Oliveira, R. B., Pereira, K. S., Azeredo, D. R. P., Sant'Ana, A S., Nascimento, J. S., \& Cruz, A. G. (2019). Predictive model for inactivation of salmonella in infant formula during microwave heating processing. Food Control, 104, 308-312. http://dx.doi.org/10.1016/j.foodcont.2019.05.006

Qian, F., Sun, J., Cao, D., Tuo, Y., Jiang, S., \& Mu, G. (2017). Experimental and modelling study of the denaturation of milk protein by heat treatment. Han-gug Chugsan Sigpum Hag-hoeji, 37(1), 44-51. PMid:28316470. http://dx.doi.org/10.5851/kosfa.2017.37.1.44

Rafe, A., \& Razavi, S. M. (2015). Effect of thermal treatment on chemical structure of $\beta$-lactoglobulin and basil seed gum mixture at different states by ATR-FTIR spectroscopy. International Journal of Food Properties, 18(12), 2652-2664. http://dx.doi.org/10.1080/10942912.2014.999864

Raikos, V. (2010). Effect of heat treatment on milk protein functionality at emulsion interfaces.A review. Food Hydrocolloids 24(4), 259-265. http://dx.doi.org/10.1016/j.foodhyd.2009.10.014

Schmitz-Schug, I., Kulozik, U., \& Foerst, P. (2016). Modeling spray drying of dairy products Impact of drying kinetics, reaction kinetics and spray drying conditions on lysine loss. Chemical Engineering Science, 141(17), 315-329. http://dx.doi.org/10.1016/j.ces.2015.11.008

Song, X., Shukla, S., \& Kim, M. (2018). Detection of Cronobacter species in powdered infant formula using immunoliposomebased immunomagnetic concentration and separation assay. Food Microbiology, 72, 23-30. PMid:29407402. http://dx.doi.org/10.1016/j.fm.2017.11.002

Souza, A. B., Costa Junior, L. C. G., Stephani, R., Oliveira, M. A. L., Perrone, I. T., \& Costa, R. G. B. (2015). Evaluation of the viscosity profile obtained for dispersions containing different proportions of Milk Protein Concentrate/Whey Protein Concentrate during simulated conditions of thermal processing. Lebensmittel-Wissenschaft + Technologie, 64(2), 536-539. http://dx.doi.org/10.1016/j.Iwt.2015.05.058

Sucupira, N. R., Xerez, A. C. P., \& de Souza, P. H. M. (2012). Perdas vitamínicas durante o tratamento térmico de alimentos. Journal of Health Sciences, 14(2), 121-128. http://dx.doi.org/10.17921/2447-8938.2012v14n2p\%25p

Thompkinson, D. K., \& Kharb, S. (2007). Aspects of infant food formulation. Comprehensive Reviews in Food Science and Food Safety, 6(4), 79-102. http://dx.doi.org/10.1111/j.1541-4337.2007.00020.x

Torres, J. K. F., Stephani, R., Tavares, G. M., Carvalho, A. F., Costa, R. G. B., Almeida, C. E. R., Almeida, M. R., Oliveira, L. F. C., Schuck, P., \& Perrone, I. T. (2017). Technological aspects of lactose-hydrolyzed milk powder. Food Research International, 101, 45-53. PMid:28941696. http://dx.doi.org/10.1016/j.foodres.2017.08.043

Vistoli, G., De Maddis, D., Cipak, A., Zarkovic, N., Carini, M., \& Aldini, G. (2013). Advanced glycoxidation and lipoxidation end products (AGEs and ALEs): an overview of their mechanisms of formation. Free Radical Research, 47(1, Suppl.1), 3-27. PMid:23767955. http://dx.doi.org/10.3109/10715762.2013.815348 
Walstra, P., Wouters, J. T. M., \& Geurts, T. J. (2006). Dairy science and technology (2nd ed.). Boca Raton: Taylor \& Francis Group.

Wei, W., Jin, Q., \& Wang, X. (2019). Human milk fat substitutes: past achievements and current trends. Progress in Lipid Research, 74, 69-86. PMid:30796946. http://dx.doi.org/10.1016/j.plipres.2019.02.001

Xu, Q., Shi, J., Yao, M., Jiang, M., \& Luo, Y. (2016). Effects of heat treatment on the antigenicity of four milk proteins in milk protein concentrates. Food and Agricultural Immunology, 27(3), 401-413. http://dx.doi.org/10.1080/09540105.2015.1117059

Zhang, Z., Yang, R., Wang, H., Ye, F., Zhang, S., \& Hua, X. (2010). Determination of lactulose in foods: a review of recent research. International Journal of Food Science \& Technology, 45(6), 1081-1087. http://dx.doi.org/10.1111/j.13652621.2010.02278.x

Zhuang, K., Li, H., Zhang, Z., Wu, S., Zhang, Y., Fox, E. M., Man, C., \& Jiang, Y. (2019). Typing and evaluating heat resistance of Bacillus cereus sensu stricto isolated from the processing environment of powdered infant formula. Journal of Dairy Science, 102(9), 7781-7793. PMid:31255274. http://dx.doi.org/10.3168/jds.2019-16392

Zou, L., Pande, G., \& Akoh, C. (2016). Infant Formula Fat Analogs and Human Milk Fat: New Focus on Infant Developmental Needs. Annual Review of Food Science and Technology, 7(1), 139-165. PMid:26934172. http://dx.doi.org/10.1146/annurevfood-041715-033120 